\title{
PENGARUH LABA BERSIH, TOTAL ARUS KAS DAN UKURAN PERUSAHAAN TERHADAP HARGA SAHAM PADA PERUSAHAAN SEKTOR ASURANSI YANG TERDAFTAR DI BURSA EFEK INDONESIA TAHUN 2014-2017
}

\author{
LISNA SILALAHI \\ SABETH SEMBIRING \\ Program Studi Akuntansi Universitas Katolik Santo Thomas Medan \\ sabethsembiring@gmail.com; silalahi_lisna@yah.co
}

\begin{abstract}
ABSTRAK
Penelitian ini bertujuan untuk membuktikan secara empiris pengaruh laba bersih, total arus kas dan ukuran perusahaan terhadap harga saham perusahaan asuransi yang terdaftar di Bursa Efek Indonesia (BEI) tahun 2014-2017. Populasi dalam penelitian ini adalah 12 perusahaan asuransi. Teknik pengambilan sampel adalah purposive sampling, sesuai dengan kriteria yang telah ditentukan sehingga diperoleh 10 perusahaan sampel dalam periode penelitian 4 tahun, sehingga jumlah seluruh sampel 40. Teknik analisis data yang digunakan dalam penelitian ini adalah regresi linier berganda. Pengujian hipotesis menggunakan uji koefisien determinasi, uji f dan uji t. Hasil uji statistik terbukti bahwa pengaruh laba bersih berpengaruh positif dan signifikan terhadap harga saham dimana nilai t hitung 4,989 $>\mathrm{t}_{\text {tabel }} 2,02819$ dan nilai signifikansi $0,000<0,05$, Total arus kas tidak mempunyai pengaruh dan tidak signifikan terhadap harga saham dimana nilai $t_{\text {hitung }} 1,926$ $<\mathrm{t}_{\text {tabel }}$ 2,02819 dan nilai signifikansi 0,062>0,05 dan ukuran perusahaan mempunyai pengaruh negatif dan signifikan terhadap harga saham dimana hasil $t_{\text {hitung }}-2,490>t_{\text {tabel }}$ 2,0289 dan nilai signifikansi $0,017<0,05$. Hasil uji secara simultan (uji F) menunjukkan bahwa laba bersih, total arus kas dan ukuran perusahaan mempunyai pengaruh dan signifikan terhadap harga saham dimana nilai $F_{\text {hitung }}$ 17,005> $F$ tabel 2,858 dan nilai signifikansi $0,000<0,05$. Hasil uji koefisien determinasi $\left(R^{2}\right)$ sebesar 0,069atau 0,69\%.Artinya, variabel bebas (Laba Bersih, Total Arus Kas dan Ukuran Perusahaan) mempunyai pengaruh terhadap Harga Saham pada perusahaan sektor Asuransiyang terdaftar di Bursa Efek Indonesia sebesar 0,069, sedangkan sisanya 93,1\% (1-0,069= $0,931)$ dipengaruhi oleh variabel lain yang tidak terungkap atau tidak diteliti dalam penelitian ini.
\end{abstract}

Kata kunci : Laba Bersih, Total Arus Kas, Ukuran Perusahaan dan Harga Saham

\section{PENDAHULUAN}

Perkembangan perekonomian yang semakin maju serta diikuti oleh pesatnya perkembangan teknologi informasi yang akan meningkatkan upaya berbagai perusahaan untuk mengembangkan usahanya dan melakukan kegiatan lebih untuk meraih dana dalam rangka perluasan usaha agar investor mendapatkan keuntungan yang lebih baik. Berdasarkan alasan tersebut, maka salah satu langkah yang dilakukan perusahaan adalah 
dengan menjual saham di pasar modal atau Bursa Efek Indonesia disingkat dengan BEI.

Dijualnya saham di pasar modal berarti masyarakat luas dalam hal ini adalah investor diberi kesempatan untuk memiliki dan mendapatkan keuntungan yang lebih baik atas pembelian saham. Tujuan perusahaan menjual saham di pasar modal adalah untuk memperoleh dana yang akan digunakan dalam pengembangan usahanya, dan untuk para pemilik modal adalah untuk mendapatkan penghasilan dari pembelian saham tersebut. Dalam aktivitas pasar modal, harga saham merupakan faktor yang sangat penting karena harga saham dapat menunjukkan prestasi suatu perusahaan, pergerakan harga saham berbanding lurus dengan kinerja suatu perusahaan.

Pada umumnya, perusahaan yang bergerak di bidang bisnis akan menyusun laporan keuangan. Laporan keuangan ini berguna untuk melihat posisi keuangan, kinerja perusahaan serta perubahan posisi keuangan perusahaan yang bermanfaat dalam pengambilan keputusan ekonomi yang nantinya akan berpengaruh bagi kemajuan perusahaan. Salah satu dari laporan keuangan adalah laporan laba rugi.

Menurut Brigham dan Houston (2001:96) menyatakan bahwa Perusahaan dengan laba yang tinggi mampu membayar dividen yang lebih tinggi sehingga dapat meningkatkan harga saham.Pada prinsipnya, investor membeli saham adalah untuk mendapatkan dividen serta menjual saham tersebut pada harga yang lebih tinggi (capital gain).

Suyanti (2017:15) Laba bersih adalah seluruh pendapatan atas seluruh biaya untuk suatu periode dikurangi pajak penghasilan yang disajikan dalam laporan laba rugi. Para akuntan menggunakan istilah "net income" untuk menyatakan kelebihan pendapatan atas biaya dan istilah "net loss" untuk menyatakan kelebihan biaya atas pendapatan.

Wahyu Widodo(2003:2). Selain laba bersih, salah satu informasi dalam laporan keuangan yang direspon oleh investor serta mempengaruhi pengambilan keputusan ekonomi adalah informasi arus kas Berdasarkan Pernyataan Standar Akuntansi Keuangan No.2 (IAI, 2009) arus kas adalah arus masuk dan arus keluar kas atau setara kas.Setara kas (cash equivalent) adalah investasi yang sifatnya sangat likuid, berjangka pendek, dan dapat dijadikan kas dalam jumlah tertentu tanpa menghadapi risiko perubahan nilai yang signifikan.

Laporan arus kas diklasifikasikan berdasarkan aktivitas operasi, investasi dan pendanaan.Laporan arus kas bertujuan untuk melaporkan penerimaan dan pengeluaran kas selama satu periode yang berasal dari 
aktivitas operasi, investasi, dan pendanaan. Laporan arus kas digunakan oleh manajemen untuk mengevaluasi kegiatan operasional yang telah berlangsung, dan merencanakan aktivitas investasi dan pendanaan dimasa yang akan datang.

Menurut Suyanti (2017: 19) arus kas adalah suatu laporan keuangan yang berisikan pengaruh kas dari kegiatan operasi, kegiatan transaksi investasi dan kegiatan transaksi pendanaan serta kenaikan atau penurunan bersih dalam kas suatu perusahaan selama satu periode.

Sutrisno(2001:25) Ukuran perusahaan adalah skala besar kecilnya perusahaan, suatu perusahaan besar yang sudah mapan akan memiliki akses yang mudah untuk menuju pasar modal. Kemudahan tersebut sangat berarti untuk fleksibilitas dan kemampuannya untuk memperoleh dana yang lebih besar, sehingga perusahaan dapat memiliki resiko pembayaran deviden yang lebih tinggi dari pada perusahaan kecil. Jadi semakin besar ukuran perusahaan maka deviden yang dibagikan juga semakin besar. Menurut Badan Standarisasi Nasionaldalam hal ukuran perusahaan dilihat dari total aset yang dimiliki oleh perusahaan, yang dapat dipergunakan untuk kegiatan operasi perusahaan.

Tamara, dkk (2013:115) ukuran perusahaan sangat bergantung pada besar kecilnya perusahaan. Perusahaan besar lebih muda memperoleh pinjaman karena nilai aktiva yang dijadikan jaminan lebih besar dan tingkat kepercayaan bank juga lebih tinggi. Aktiva yang dijaminkan dapat berupa aktiva tetap berwujud serta aktiva lainnya seperti piutang dagang dan persediaan. Makin besar ukuran sebuah perusahaan maka harga saham semakin tinggi, sedangkan jika ukuran perusahaan semakin kecil maka harga saham akan semakin rendah.

Suyanti (2017:4) menyebutkan bahwa harga saham adalah nilai dari penyertaan atau kepemilikan seseorang dalam suatu perusahaan. Semakin banyak investor yang ingin membeli atau menyimpan suatu saham, maka harganya akan semakin naik. Dan sebaliknya jika semakin banyak investor yang menjual atau melepaskan maka akan berdampak pada turunnya harga saham. Harga saham merupakan salah satu indikator keberhasilan pengelolaan perusahaan. Harga saham senantiasa bergerak dan pergerakan tersebut ditentukan oleh kekuatan permintaan dan penawaran saham itu sendiri di pasar modal. Bagi investor, harga saham mencerminkan nilai suatu perusahaan.

Menurut Brigham dan Houston (2006:33) faktor-faktor yang mempengaruhi harga saham dapat berasal dari faktor internal maupun eksternal. Adapun faktor internal perusahaan antara lain adalah laba bersih, 
ukuran perusahan, pengumuman laporan keuangan perusahaan yang meliputi laporan arus kas, tingkat resiko arus kas yang diterima dan lainlain. Sedangkan faktor eksternal yang dapat mempengaruhi harga saham adalah batasan hukum, tingkat umum aktivitas ekonomi, undang-undang pajak, tingkat suku bunga dan kondisi bursa saham.

Perusahaan asuransi adalah lembaga yang menyediakan berbagai polis asuransi untuk melindungi seseorang atau nasabahnya dari berbagai macam resiko kerugian dengan cara membayar premi secara teratur, perusahaan asuransi bekerja dengan cara menyatukan resiko dari sejumlah pemegang polis asuransi. Polis asuransi adalah suatu perjanjian asuransi ataupun pertanggungan yang sifatnya konsensual atau terdapat kesepakatan. Polis asuransi ini harus dibuat secara tertulis dalam suatu akta antara pihak-pihak yang mengadakan perjanjian, dan pada akta yang dibuat secara tertulis tersebutlah yang dinamakan polis asuransi. Jadi polis asuransi yaitu suatu tanda bukti tertulis kesepakatan antara pihak tertanggung (nasabah) dan pihak penanggung (perusahaan asuransi). Beberapa jenis asuransi adalah asuransi jiwa, asuransi kesehatan, asuransi pendidikan, asuransi kendaraan.

Berdasarkan latar belakang diatas maka penelitian ini bermaksud untuk menganalisis Apakah laba bersih, total arus kas dan ukuran perusahaan berpengaruh terhadap harga saham pada perusahaan sektor Asuransi yang terdaftar di Bursa Efek Indonesia tahun 2014-2017?"

\section{TINJAUAN PUSTAKA}

\section{Teori Sinyal (Signalling Theory)}

Irham Fahmi (2014 : 21) Signalling theory adalah teori yang membahas tentang naik turunnya harga di pasar seperti harga saham, obligasi dan sebagainya sehingga akan memberi pengaruh pada keputusan investor.

Signalling theory menekankan kepada pentingnya informasi yang dikeluarkan oleh perusahaan terhadap keputusan investasi pihak di luar perusahaan. Informasi merupakan unsur penting bagi investor dan pelaku bisnis karena informasi pada dasarnya menyajikan keterangan, catatan atau gambaran baik untuk keadaan masa lalu, saat ini maupun keadaan masa yang akan datang bagi kelangsungan hidup suatu perusahaan dan bagaimana pasaran efeknya. Informasi yang lengkap, relevan, akurat dan tepat waktu sangat diperlukan oleh investor di pasar modal sebagai alat analisis untuk mengambil keputusan investasi. 
Semua investor memerlukan informasi untuk mengevaluasi risiko relatif setiap perusahaan sehingga dapat melakukan diversifikasi portofolio dan kombinasi investasi dengan preferensi risiko yang diinginkan.Jika suatu perusahaan ingin sahamnya dibeli oleh investor maka perusahaan harus melakukan pengungkapan laporan keuangan secara terbuka dan transparan.

Hubungan teori signal dengan penelitian ini menunjukkan bahwa apabila laba bersih, total arus kas dan ukuran perusahaan yang dilaporkan oleh perusahaan meningkat maka informasi tersebut dapat dikategorikan sebagai sinyal baik karena mengindikasikan kinerja keuangan dan kondisi perusahaan yang baik.

\section{Laba Bersih}

Hery (2009:145) Untuk menentukan keputusan investasinya, calon investor perlu menilai perusahaan dari segi kemampuannya untuk memperoleh laba bersih sehingga diharapkan perusahaan dapat memberikan tingkat pengembalian yang tinggi dan kemampuan perusahaan dalam membayar dividen.Laba bersih berasal dari transaksi pendapatan, beban, keuntungan dan kerugian Laba bersih (netincome atau earning) dapat dijadikan sebagai suatu ukuran kinerja perusahaan dalam satu periode tertentu.

Pengertian laba bersih menurut kamus akuntansi cetakan kedua oleh Ibrahim Abdullah (1993:289) Laba bersih adalah seluruh pendapatan atas seluruh biaya untuk suatu periode dikurangi pajak penghasilan yang disajikan dalam laporan laba rugi. Para akuntan menggunakan istilah "net income" untuk menyatakan kelebihan pendapatan atas biaya dan istilah net loss" untuk menyatakan kelebihan biaya atas pendapatan.

\section{Klasifikasi Arus Kas}

Menurut Kieso dkk (2005:324) laporan arus kas menggolongkan penerimaan kas dan pembayaran kas menjadi tiga aktivitas, yaitu:

1) Aktivitas operasi

Aktivitas operasi mencakup pengaruh kas dari transaksi yang menghasilkan pendapatan dan beban.Pendapatan dan beban yang kemudian dimasukkan dalam penentuan laba bersih.

Jumlah arus kas yang berasal dari aktivitas operasi merupakan indikator utama untuk menentukan apakah dari operasi entitas dapat menghasilkan arus kas yang cukup untuk melunasi pinjaman, memelihara 
kemampuan operasi entitas, membayar dividen, dan melakukan investasi baru tanpa mengandalkan sumber pendanaan dari luar.

2) Aktivitas investasi

Aktivitas investasi mencakup memperoleh dan menjual investasi dan aset tetap, dan meminjam uang dan menagih pinjaman.

3) Aktivitas pendanaan

Aktivitas pendanaan mencakup memperoleh kas dari penerimaan utang dan membayarkan jumlah yang dipinjam, serta memperoleh kas dari pemegang saham dan memberikan pengembalian atas investasi pemegang saham.

Sesuai dengan penggolongan arus kas yang dikemukakan oleh teori sebelumnya, maka arus kas yang digunakan dalam penelitian ini berasal dari tiga aktivitas, yaitu arus kas operasi, arus kas investasi, dan arus kas pendanaan.Ketiga aktivitas tersebut dapat diketahui dalam laporan arus kas pada laporan tahunan yang dipublikasikan setiap perusahaan.

Laporan arus kas bermanfaat bagi para investor, kreditor, dan lainnya adalah untuk menilai

1. Kemampuan entitas dalam memperoleh arus kas dimasa depan

Laporan keuangan arus kas lebih baik dibandingkan data akrual. Para pihak pemakai dapat membuat prediksi mengenai jumlah, waktu dan ketidakpastian mengenai arus kas di masa depan dengan memeriksa hubungan antar pos pada laporan arus kas.

2. Kemampuan entitas untuk membayar deviden dan memenuhi kewajiban.

Dengan melihat laporan arus kas maka perusahaan dapat memastikan jumlah/nominal kas perusahaan untuk membayar sejumlah kewajiban seperti membayar gaji karyawan, melunasi hutang atau membayar deviden.Para investor dan pemakai informasi keuangan lainnya tertarik pada laporan arus kas karena menggambarkan arus kas dalam kegiatan bisnis.

3. Alasan atas perbedaan antara angka laba bersih dan kas bersih yang dihasilkan (digunakan) oleh aktivitas operasi.

Keberhasilan atau kegagalan sebuah perusahaan bisnis dapat dilihat dari laba bersih yang didapatkan.Sehingga informasi atas laba bersih juga sangat di butuhkan oleh para pihak-pihak pemakai laporan keuangan.

4. Transaksi investasi dan pendanaan kas selama periode tersebut. Jumlah aset dan kewajiban sewaktu-waktu dapat berubah dikarenakan faktor-faktor tertentu. Dengan memeriksa transaksi investasi dan 
pendanaan, pemakai informasi akan dapat mengetahui penyebab perubahan kedua akun tersebut.

Laporan arus kas didefenisikan oleh Kieso dkk (2005:323) "laporan arus kas melaporkan penerimaan kas, pembayaran kas, dan perubahan bersih pada kas yang dihasilkan dari aktivitas operasi, investasi, dan pendanaan selama satu periode”. Total Arus Kas dapat dihitung dengan:

Total Arus Kas = Arus Kas Operasi + Arus Kas Investasi + Arus Kas Pendanaan

\section{Ukuran Perusahaan}

Suwito dan Herawaty (2005:12) Ukuran perusahaan pada dasarnya adalah pengelompokkan perusahaan kedalam beberapa kelompok, diantaranya perusahaan besar, sedang dan kecil. Skala perusahaan merupakan ukuran yang dipakai untuk mencerminkan besar kecilnya perusahaan yang didasarkan kepada total aset perusahaan

Menurut Tamara, dkk (2013:3) ukuran perusahaan adalah suatu ukuran yang menunjukkan besar kecilnya suatu perusahaan, antara lain total penjualan, rata-rata tingkat penjualan dan total aktiva. Pada umumnya perusahaan besar memiliki total aktiva yang besar pula sehingga dapat menarik investor untuk menanamkan modalnya pada perusahaan tersebut dan akhirnya saham tersebut mampu bertahan dalam harga yang tinggi.

Menurut Brigham dan Houston (1999:118) ukuran perusahaan adalah rata-rata total penjualan bersih untuk tahun yang bersangkutan sampai beberapa tahun kemudian. Dalam hal ini penjualan lebih besar dari pada biaya variabel dan biaya bebas, maka akan diperoleh jumlah pendapatan sebelum pajak.

Rima Fahmi Utami (2013:22) ukuran perusahaan merupakan nilai yang menunjukkan besar kecilnya perusahaan. Besar kecilnya perusahaan dilihat dari besar nilai equity, nilai penjualan atau nilai aktiva. Perusahaan dengan ukuran besar memiliki akses lebih besar dan luas untuk mendapat sumber pendanaan dari luar, sehingga untuk memperoleh pinjaman akan menjadi lebih mudah karena dikatakan bahwa perusahaan dengan ukuran besar memiliki kesempatan lebih besar untuk memenangkan persaingan atau bertahan dalam industri. Perusahaan besar memiliki total aset yang lebih besar pula sehingga dapat menarik investor untuk menanamkan modalnya pada perusahaan tersebut.

Ukuran perusahaan adalah suatu skala dimana-mana dapat diklasifikasikan besar kecil perusahaan menurut berbagai cara, antara lain 
total aset, log size nilai pasar saham dan lain-lain. Berdasarkan total aset, ukuran perusahaan terbagi dalam tiga kategori yaitu perusahaan besar, perusahaan menengah dan perusahaan kecil. Perusahaan yang memiliki total aset besar menunjukkan bahwa perusahaan tersebut telah mencapai tahap kedewasaan.

Ukuran perusahaan adalah besar kecilnya perusahaan yang didasarkan pada total aktiva (total asset) perusahaan. Aset perusahaan digolongkan menjadi dua, yaitu aktiva lancar dan aktiva tidak lancar. Aktiva lancar yaitu kas, investasi jangka pendek, tanah, bangunan, mesin, kendaraan, peralatan. Sedangkan aktiva tidak lancar yaitu aktiva tetap, investasi jangka panjang, dan aktiva tidak berwujud. Dilihat Penelitian ukuran perusahaan dapat menggunakan tolak ukur aset, karena total aset perusahaan bernilai besar maka dalam proses perhitungan nilai total aset dapat disederhanakan dengan mentranformasikan ke dalam logaritma natural. Ghozali (2006:12) secara matematisukuran perusahaan dapat diformulasikan sebagai berikut :

$$
\text { Ukuran Perusahaan }=\text { Ln }(\text { total aset })
$$

\section{Harga Saham}

Harga saham merupakan salah satu indikator pengelolaanperusahaan.Ketika harga saham mengalami peningkatan darisebelumnya dapat diartikan jika perusahaan mengelola aktiva denganbaik. Harga saham yang cukup tinggi akan memberikan keuntunganberupa capital gain dan citra yang lebih baik bagi perusahaandihadapan investor dan calon investor sehingga dapat memudahkanperusahaan untuk mendapatkan dana dari luar perusahaan untukkeberlangsungan aktivitas perusahaan

Dipergunakannya saham sebagai salah satu alat untuk mencari tambahan dana menyebabkan kajian dan analisis tentang saham begitu berkembang baik secara fundamental dan teknikal. Berbagai literatur mencoba memberikan rekomendasi yang berbeda- beda namun tujuannya sama yaitu ingin memberikan profit yang tinggi bagi pemakainya, serta memiliki dampak keputusan yang bersifat berkelanjutan. Ada banyak pihak yang terlibat dalam bermain di pasar saham, secara umum ada tiga yaitu investor, spekulan, dan government.

Menurut Tandelilin(2007:19)harga saham merupakan harga yang terjadi di pasar saham, yang akansangat berarti bagi perusahaan karena harga tersebut menentukanbesarnya nilai perusahaan. Menurut Jogiyanto (2018:167) harga saham adalah harga suatu saham yang terjadi di pasar 
bursa pada saat tertentu yang ditentukan olehpermintaan dan penawaran saham yang bersangkutan dipasar modal.

Dari pengertian harga saham menurut para ahli dapat disimpulkan bahwa harga saham adalah harga yang terbentuk sesuai permintan dan penawaran dipasar jual beli saham dan biasanya harga penutupan.

\section{Gambar 1. Kerangka Pemikiran}

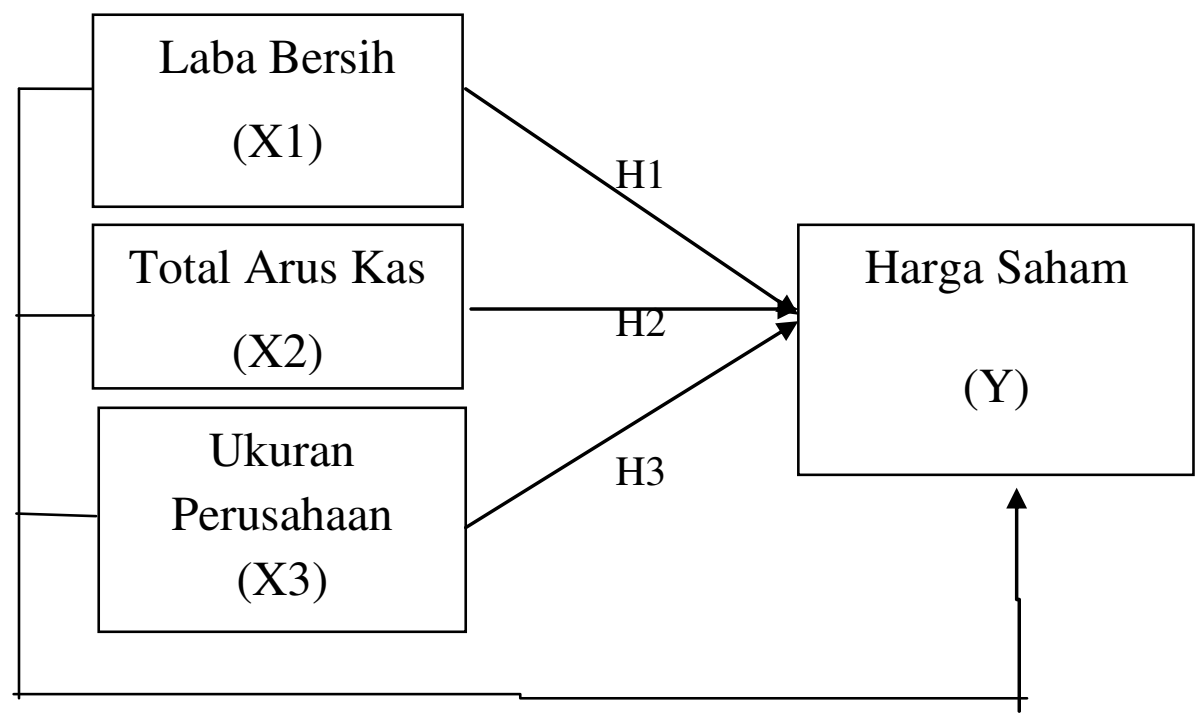

\section{Hipotesis}

Hipotesis peneliatin ini dirumuskan sebagia berikut:

H1 : Laba bersih berpengaruh positif signifikan terhadap harga saham $\mathrm{H} 2$ : Total arus kas berpengaruh positif signifikan terhadap harga saham H3 : Ukuran perusahaan berpengaruh positif signifikan terhadap harga saham

\section{METODE PENELITIAN}

\section{Populasi dan Sampel}

Populasi merupakan keseluruhan objek yang akan diteliti. Populasi penelitian ini adalah seluruh perusahaan sektor asuransi yang terdaftar di Bursa Efek Indonesia periode 2014-2017.Perusahaan sektor asuransi yang terdaftar di Bursa Efek Indonesia dari tahun 2014-2017 sebanyak 12 perusahaan. 
Menurut Suyanti (2017: 40) Sampel adalah sebagian dari populasi yang diteliti. Pemilihan sampel dalam penelitian ini menggunakan metodepurposive sampling yaitu pemilihan sampel tidak acak yang informasinya diperoleh dengan pertimbangan tertentu.1. Perusahaan sektor asuransi yang terdaftar di Bursa Efek Indonesia (BEI) sejak tanggal 1 Januari 2014 sampai dengan 31 Desember 2017. 2. Perusahaan yang menerbitkan laporan keuangan auditan dan dipublikasikan pada periode 2014-2017.3. Laporan keuangan disajikan dalam mata uang rupiah. 4. Jumlah sampel yang memenuhi kriteria dalam penelitian ini adalah sebanyak 10 perusahaan.

\section{Operasionalisasi Variabel}

Operasionalisasi variabel adalah penjelasan tentang variabelvariabel yang akan diteliti. Adapun variabel-variabel yang akan diteliti dikelompokkan sebagai berikut:

a. Harga saham

Harga saham adalah nilai dari penyertaan atau kepemilikan seseorang dalam suatu perusahaan. Keberhasilan dalam menghasilkan keuntungan akan memberikan suatu kepuasan bagi investor yang rasional. Indikator yang digunakan Closing Price (Harga Penutupan) pada saat penerbitan laporan keuangan yang telah diaudit kurang lebih 3 bulan yaitu pada bulan maret. Skala Pengukurannya adalah Skala Nominal dalam satuan rupiah.

b. Laba bersih.

Warren et al. (2006:25) menyatakan, laba bersih yaitu selisih lebih pendapatan terhadap beban. Laba bersih diformulasikan dengan : Laba Bersih Setelah Pajak

c. Total Arus Kas

$$
\text { Laba }=\text { Pendaatan }- \text { Beban }
$$

Total arus kas merupakan jumlah arus kas dari aktivitas operasi, investasi, pendanaan dan kas dan setara kas awal tahun. Untuk tujuan analisis melalui regresi, sebelumnya total arus kas dihitung besar perubahannya untuk setiap tahun. Perubahan total arus kas ini merupakan variabel bebas pada agresi linier sederhana yang digunakan untuk analisis pengaruh informasi total arus kas terhadap harga saham.

Total Arus Kas = Arus Kas Oerasi + Arus Kas Investasi + Arus Kas Pendanaan 
d. Ukuran Perusahaan

Ukuran Perusahaan yaitu besar kecilnya perusahaan yang didasarkan pada total aktiva (total aset) perusahaan. Ukuran perusahaan dalam penelitian ini diukur dari logaritma natural total aktiva yang dimiliki perusahaan. Logaritma Natural digunakan karena satuan pada total aset suatu perusahaan dapat bernilai triliunan sehingga dalam ekonometrika akan bermasalah (Ichwan, Fith Yuniar (2015), oleh karena itu salah satu cara untuk menyederhanakannya adalah melalui ln (logaritma natural) dengan menggunakan rumus :

$$
\text { Ukuran Perusahaan }=\operatorname{Ln}(\text { Total Asset })
$$

\section{Teknik Analisis Data}

Penelitian ini menggunakan teknik analisis regresi linier berganda (multiple regression analysis model) yaitu analisis yang digunakan untuk mengetahui besarnya pengaruh variabel independent terhadap variabel dependent dengan model dasar sebagai berikut:

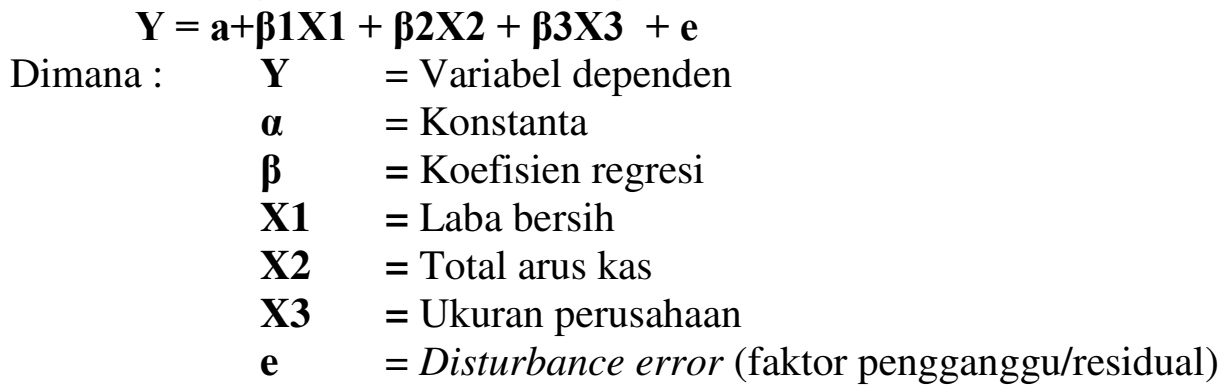

\section{Pengujian Hipotesis}

a. Koefisien Determinasi (R2)

Koefisien determinasi $\left(\mathrm{R}^{2}\right)$ merupakan alat ukur seberapa jauh kemampuan model dalam menerangkan variasi variabel independen dalam menjelaskan variasi variable-variabel dependen amat terbatas. Nilai yang mendekati satu berarti variable-variabel independen memberikan hampir semua informasi yang dibutuhkan untuk memprediksi variasi variabel independen.

\section{b. Uji t}

Pengujian ini dilakukan untuk mengetahui apakah terdapat pengaruh signifikan dari laba bersih, total arus kas dan ukuran perusahaan secara parsial terhadap harga saham pada perusahaan sektor asuransi yang terdaftar di Bursa Efek Indonesia untuk periode 2014-2017. 
c. Uji F

Uji $F$ dilakukan untuk mengetahui apakah terdapat pengaruh signifikan dari laba bersih, total arus kas dan ukuran perusahaan secara simultan terhadap harga saham pada perusahaan kelompok sektor asuransi yang terdaftar di Bursa Efek Indonesia untuk periode 2014-2017.

\section{HASIL PENELITIAN DAN PEMBAHASAN}

\section{Hasil Pengujian Asumsi Klasik}

Hipotesis penelitian diuji dengan menggunakan teknik analisis regresi linear berganda. Menurut Ghozali (2005) untuk menghasilkan suatu analisis data yang akurat, suatu persamaan regresi sebaiknya terbebas dari asumsi-asumsi klasik yang harus dipenuhi antara lain uji normalitas, multikolinearitas, autokoloresai dan heteroskedastisitas. Jika keseluruhan syarat tersebut terpenuhi, berarti bahwa model analisis telah layak digunakan. Uji asumsi klasik dapat dijabarkan sebagai berikut:

\section{a. Uji Normalitas}

Uji normalitas bertujuan untuk menguji apakah dalam model regresi, variabel terikat dan variabel independen keduanya memiliki distribusi normal atau tidak. Model regresi yang baik adalah memiliki distribusi normal atau mendekati normal. Uji normalitas bertujuan untuk melihat apakah model regresi, variabel pengganggu atau residual berdistribusi normal.

Tabel 1. One-sample Kolmogorov-Sminorv Test

One-Sample Kolmogorov-Smirnov Test

\begin{tabular}{|c|c|c|}
\hline & & $\begin{array}{l}\text { Unstandardized } \\
\text { Residual }\end{array}$ \\
\hline $\mathrm{N}$ & & 40 \\
\hline Normal Parameters ${ }^{\mathrm{a}, \mathrm{b}}$ & Mean & ,0000000 \\
\hline Most Extreme & Std. Deviation & 6375,32236200 \\
\hline Differences & Absolute & , 100 \\
\hline & Positive & ,096 \\
\hline & Negative &,- 100 \\
\hline Test Statistic & & 100 \\
\hline Asymp. Sig. (2-tailed) & & ,200 \\
\hline
\end{tabular}

Ket : a. Test distribution is Normal.

b. Calculated from data.

Sumber: Hasil output SPSS 24,2018 (data diolah) 
Dari tabel 1 dapat dilihat bahwa besarnya nilai Kolmogorov Sminorv adalah 0,100 dan signifikan pada 0,200 maka dapat disimpulkan bahwa data tersebut terdistribusi dengan normal.

\section{b. Uji Multikolinearitas}

Multikolinearitas merupakan fenomena adanya korelasi yang sempurna antara satu variabel independen dengan variabel dependen lain.

Tabel 2 Uji Multikolinearitas

\section{Coefficients $^{\mathrm{a}}$}

\begin{tabular}{|r|l|r|r|r|r|r|}
\hline \multicolumn{2}{|l|}{ Model } & \multicolumn{2}{|c|}{$\begin{array}{c}\text { Unstandardized } \\
\text { Coefficients }\end{array}$} & $\begin{array}{c}\text { Standardized } \\
\text { Coefficients }\end{array}$ & \multicolumn{2}{c|}{ Collinearity Statistics } \\
\cline { 3 - 7 } \multicolumn{2}{|c|}{} & \multicolumn{1}{|c|}{ B } & Std. Error & \multicolumn{1}{c|}{ Beta } & \multicolumn{1}{c|}{ Tolerance } & VIF \\
\hline 1 & (Constant) & 25028,275 & 9478,798 & & & \\
\hline & Laba Bersih &, 186 &, 036 &, 876 &, 373 & 2,682 \\
\hline & Total Arus Kas &, 134 &, 083 &, 280 &, 545 & 1,836 \\
\hline & $\begin{array}{l}\text { Ukuran } \\
\text { perusahaan }\end{array}$ & - & 437,584 &,- 446 &, 359 & 2,782 \\
\hline
\end{tabular}

Ket : a. Dependent Variable: Harga Saham

Sumber : Hasil Output SPSS 24, 2018 (data diolah)

Dari tabel 2 tersebut dapat dilihat bahwa nil VIF (Variance Inflation Factor) untuk variabel independen Laba Bersih $=2,682$; total arus kas $=1,836$; dan laba bersih $=2,782$ masing-masing $<10$ serta memiliki nilai tolerance $>0,10$ yaitu laba bersih $=0,876$ total arus $\mathrm{kas}=$ 0,280 ; dan laba bersih $=-0,446$ dapat disimpulkan bahwa tidak terdapat gejala multikolinearitas.

\section{c. Uji Autokorelasi}

Uji Autokorelasi bertujuan menguji apakah dalam sebuah model regresi linier ada korelasi antara kesalahan pengganggu pada periode $t$ dengan kesalahan pada periode t-1 (sebelumnya).

Tabel 3 Hasil Uji Autokorelasi (Durbin Waston) Model Summary ${ }^{\mathrm{b}}$

\begin{tabular}{|l|c|r|r|r|r|}
\hline Model & $\mathrm{R}$ & $\begin{array}{c}\mathrm{R} \\
\text { Square }\end{array}$ & $\begin{array}{c}\text { Adjusted R } \\
\text { Square }\end{array}$ & $\begin{array}{c}\text { Std. Error of } \\
\text { the Estimate }\end{array}$ & $\begin{array}{c}\text { Durbin- } \\
\text { Watson }\end{array}$ \\
\hline 1 &, $375^{\mathrm{a}}$ &, 140 &, 069 & 1,09411 & 2,044 \\
\hline
\end{tabular}

Ket: a. Predictors:(Constant),Ukuran perusahaan,Total Arus Kas,Laba Bersih b. Dependent Variable: Harga Saham

Sumber : Hasil Output SPSS 24, 2018 (data diolah) 
Berdasarkan tabel 3 diatas, terlihat nilai Durbin-Watson sebesar 2,044 untuk mengetahui adanya autokorelasi digunakan uji DurbinWatson, Ghozali menentukan nilai Durbin-Watson (DW) yaitu dengan DW sebesar 2,044 akan dibandingkan dengan nilai tabel dengan menggunakan $\alpha=5 \%, \mathrm{n}=40, \mathrm{k}=3$ berdasarkan tabel DW didapatkan nilai batas bawah $(\mathrm{dL})=1,3384$ dan nilai batas atas $(\mathrm{dU})=1,6589$. Oleh karena $\mathrm{dU}<\mathrm{d}<4-\mathrm{dU},(1,6589<2,044<2,3411)$. Hasil tersebut menunjukkan bahwa model yang digunakan tidak ada autokorelasi positif maupun negatif (bebas uji autokorelasi) pada persamaan regresi dalam penelitian ini.

\section{d. Hasil Uji Heteroskedastisitas}

Pengujian ini bertujuan untuk menguji apakah terjadi ketidaksamaan varian dari residual satu pengamatan ke pengamatan lain dalam model regresi. Model penelitian yang baik adalah homoskedastisitas, yaitu varian danresidual satu pengamatan ke pengamatan yang lain hasilnya tetap.

\section{Gambar 1..Grafik Scatterplot}

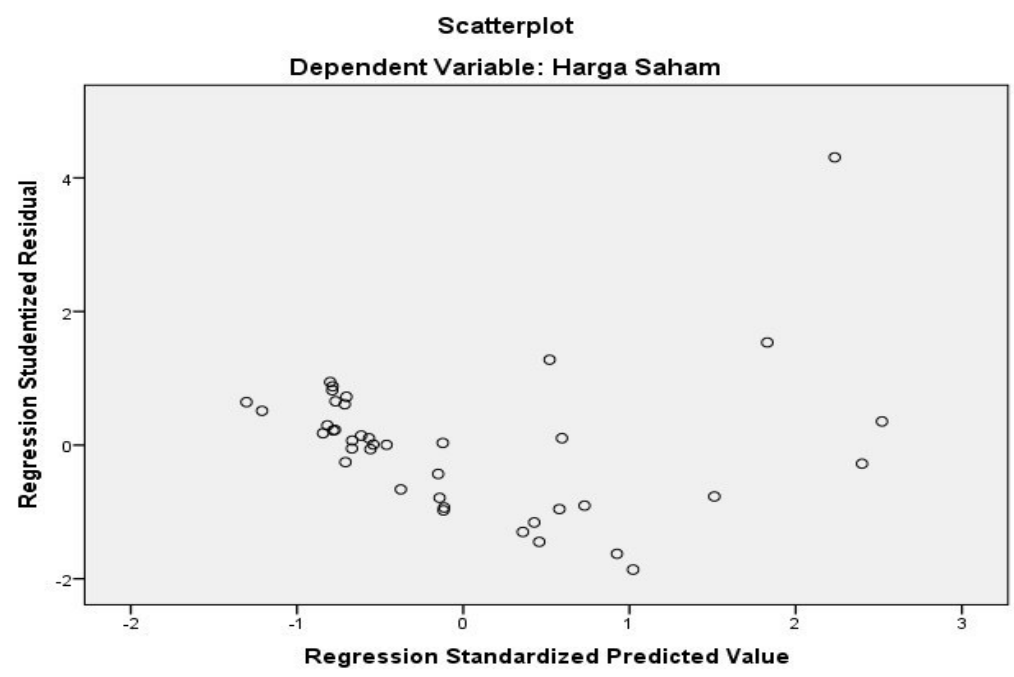

Suatu yang dikatakan tidak heteroskedastisitas jika tdak ada pola yang jelas seperti titik-titik menyebar diatas dan dibawah angka nol pada sumbu Y, maka tidak tejadi heteroskedastisitas. Dengan melihat grafik scatterplot, terlihat titik-titik menyebar secara acak, serta tersebar baik di atas maupun di bawah angka 0 pada sumbu Y. Maka dapat diambil kesimpulan bahwa tidak terdapat gejala heteroskedastisitas pada model regresi yang digunakan. 


\section{Model Penelitian}

Analisis linear berganda digunakan untuk mengetahui pengaruh penjualan, arus kas dan laba bersih terhadap harga saham.Analisis ini diolah dengan program SPSS 24. Hasil analisis regresi linear berganda ditunjukkan pada tabel berikut:

Tabel 4. Hasil Analisis Regresi

\section{Coefficients $^{a}$}

\begin{tabular}{|r|r|r|r|r|r|r|}
\hline \multicolumn{2}{|c|}{ Model } & \multicolumn{2}{|c|}{$\begin{array}{c}\text { Unstandardized } \\
\text { Coefficients }\end{array}$} & $\begin{array}{c}\text { Standardized } \\
\text { Coefficients }\end{array}$ & \multirow{2}{*}{ T } & \multirow{2}{*}{ Sig. } \\
\cline { 3 - 5 } \multicolumn{2}{|c|}{} & \multicolumn{1}{|c|}{ B } & Std. Error & \multicolumn{1}{|c|}{ Beta } & \\
\hline \multirow{2}{*}{1} & (Constant) & $25.028,275$ & $9.478,79$ & & 2,640 &, 012 \\
& Laba Bersih &, 186 & 8 &, 876 & 4,989 &, 000 \\
& Total Arus Kas &, 134 &, 036 &, 280 & 1,926 &, 062 \\
& Ukuran & $-1.090,515$ &, 083 &,- 446 & $-2,492$ &, 017 \\
& perusahaan & & 437,584 & & & \\
\hline
\end{tabular}

Ket: a. Dependent Variable: Harga Saham

Sumber: Hasil Output SPSS 24, 2018 (data diolah)

Berdasarkan hasil tabel diatas, maka persamaan regresinya yaitu: $\mathrm{Y}=25.028,275+0,186 \mathrm{X} 1+0,134 \mathrm{X} 2-1090,515 \mathrm{X} 3+\mathrm{e}$

Berdasarkan persamaan regresi tersebut dapat dianalisis pengaruh masing-masing variabel independen terhadap harga saham, yaitu :

a. Nilai konstanta sebesar 25.028,275, menjelaskan bahwa jika variabel laba bersih, total arus kas dan ukuran perusahaan dianggap konstan, maka harga saham sebesar 25.028,275.

b. Nilai koefisien regresi 0,186 (X1) pada variabel laba bersih terdapat hubungan positif dengan harga saham. Hal ini menunjukkan setiap kenaikan 1\% dari laba bersih akan menyebabkan kenaikan harga saham yang diterima sebesar nilai koefisiennya.

c. Nilai koefesien regresi 0,134 (X2) pada variabel total arus kas terdapat hubungan positif dengan harga saham. Hal ini menunjukkan setiap kenaikan 1\% dari total arus kas akan menyebabkan kenaikan harga saham yang diterima sebesar nilai koefisiennya.

d. Nilai koefisien regresi -1.090,515 (X3) pada variabel ukuran perusahaan terdapat hubungan negatif dengan harga saham. Hal ini menunjukkan setiap kenaikan $1 \%$ dari ukuran perusahaan akan menyebabkan penurunan harga saham yang diterima sebesar nilai koefisiennya. 


\section{Koefisien Determinasi $\left(\mathbf{R}^{2}\right)$}

Analisis determinasi dalam regresi linear berganda digunakan untuk mengetahui persentase sumbangan pengaruh variabel independen secara serentak terhadap variabel dependen.Koefisien ini menunjukkan seberapa besar persentase variasi variabel independen yang digunakan dalam model mampu menjelaskan variasi variabel dependen.

Tabel 5. Hasil Uji Koefisien Determinasi

\begin{tabular}{|l|c|c|c|c|c|}
\hline Model & $\mathrm{R}$ & $\begin{array}{c}\mathrm{R} \\
\text { Square }\end{array}$ & $\begin{array}{c}\text { Adjusted R } \\
\text { Square }\end{array}$ & $\begin{array}{c}\text { Std. Error of } \\
\text { the Estimate }\end{array}$ & $\begin{array}{c}\text { Durbin- } \\
\text { Watson }\end{array}$ \\
\hline 1 &, $375^{\text {a }}$ &, 140 &, 069 & 1,09411 & 2,044 \\
\hline
\end{tabular}

Ket: a. Predictors: (Constant), Ukuran perusahaan, Total Arus Kas, Laba Bersih

b. Dependent Variable: Harga Saham

Sumber: Hasil Output SPSS 24, 2018 (data diolah)

Berdasarkan tabel 6. diatas diperoleh nilai koefisien determinasi $\left(\mathrm{R}^{2}\right.$ ) sebesar 0,069atau 0,69\% Artinya, variabel bebas (Laba Bersih, Total Arus Kas dan Ukuran Perusahaan) mempunyai pengaruh terhadap Harga Saham pada perusahaan sektor Asuransiyang terdaftar di Bursa Efek Indonesia sebesar 0,069, sedangkan sisanya 93,1\% $(1-0,069=0,931)$ dipengaruhi oleh variabel lain yang tidak terungkap atau tidak diteliti dalam penelitian ini.

\section{Pengujian Hipotesis}

Dari pengujian asumsi dapat disimpulkan bahwa data yang ada berdistribusi, tidak terdapat autokorelasi, multikolinearitas, dan heteroskedastisitas, sehingga memenuhi persyaratan untuk melakukan pengujian atas hipotesis.Pengujian hipotesis menggunakan uji $t$ dan uji $F$.

\section{a. Uji Parsial (Uji Statistik t)}

Uji t dilakukan untuk mengetahui pengaruh antara variabelvariabel independen terhadap variabel dependen secara parsial (individu). Dengan menggunakan tingkat signifikan $(\alpha=5 \%)$, jika nilai signifikan $\mathrm{t}>$ 0,05 maka hipotesisditolak, artinya tidak terdapat pengaruh yang signifikan secara parsial dari variabel independen terhadap variabel dependen. Sebaliknya, jika nilai signifikan $\mathrm{t}<0,05$ maka hipotesis diterima, artinya terdapat pengaruh yang signifikan secara parsial dari variabel independen dan variabel dependen. 
Tabel 6 Hasil (Uji Statistik t)

\begin{tabular}{|l|l|r|r|r|r|r|}
\hline \multicolumn{2}{|c|}{ Model } & \multicolumn{2}{|c|}{ Unstandardized Coefficients } & $\begin{array}{l}\text { Standardized } \\
\text { Coefficients }\end{array}$ & T & Sig. \\
\hline 1 & \multicolumn{1}{|c|}{ B } & Std. Error & \multicolumn{1}{c|}{ Beta } & & \\
\hline & Constant) & $25.028,275$ & $9.478,798$ & & 2,640 &, 012 \\
\hline &, 186 &, 036 &, 876 & 4,989 &, 000 \\
\hline & Taba Bersih &, 134 &, 083 &, 280 & 1,926 &, 062 \\
\hline & $\begin{array}{l}\text { Tkural Arus Kas } \\
\text { perusahaan }\end{array}$ & $-1.090,515$ & 437,584 &,- 446 & $-2,492$ &, 017 \\
\hline
\end{tabular}

Ket: Dependent Variable: Harga Saham

Sumber: Hasil Output SPSS 24, 2018 (data diolah)

Berdasarkan hasil uji secara parsial pada tabel 6, laba bersih memiliki sig. sebesar 0,000 dimana $0,000<0,05$ dan nilai $t_{\text {hitung }} 4,989>$ 2,02819, sehingga Ho ditolak dan Ha diterima. Dengan demikian, dapat diambil kesimpulan bahwa laba bersih berpengaruh positif dan signifikan terhadap harga saham.

Berdasarkan hasil uji secara parsial pada tabel 6, total arus kas memiliki sig. sebesar 0,062 dimana 0,062>0,05 dan nilai $t_{\text {hitung }} 1,926<$ 2,02819, sehingga Ho diterima dan Ha ditolak. Dengan demikian, dapat diambil kesimpulan bahwa total arus kas tidak berpengaruh dan tidak signifikan terhadap harga saham.

Berdasarkan hasil uji secara parsial pada tabel 6, ukuran perusahaan memiliki sig. sebesar 0,017 dimana $0,017<0,05$ dan nilai $\mathrm{t}_{\text {hitung }}-2,490>2,02819$, sehingga Ho ditolak dan Ha diterima. Dengan dmikian, dapat diambil kesimpulan bahwa ukuran perusahaan berpengaruh negatif dan signifikan terhadap harga saham.

\section{b. Uji Simultan (Uji Statistik F)}

Pengujian ini dimaksudkan untuk mengetahui pengaruh antara variabel independen dan variabel dependen secara bersama-sama (simultan).Signifikansi model regresi secara simultan diuji dengan melihat perbandingan antara F-tabel dan F-hitung. Selain itu akan diihat nilai signifikansi, dimana jika nilai signifikan dibawah 0,05 maka variabel independen dinyatakan berpengaruh terhadap variabel dependen. Uji $\mathrm{F}$ digunakan untuk menguji hubungan regresi antar variabel independendengan seperangkat terhadap variabel dependen. 
Tabel 7 Uji Simultan (Uji Statistik F)

\begin{tabular}{|l|l|l|r|r|r|c|}
\multicolumn{7}{|c|}{ ANOVA $^{\text {a }}$} \\
\hline \multirow{2}{*}{1} & Model & Sum of Squares & \multicolumn{1}{c|}{ Df } & \multicolumn{1}{c|}{ Mean Square } & \multicolumn{1}{c|}{ F } & \multicolumn{1}{c|}{ Sig. } \\
\cline { 2 - 8 } & Regression & $2.246 .284 .784,000$ & 3 & $748.761 .594,700$ & 17,005 &, $000^{b}$ \\
\cline { 2 - 8 } & Residual & $1.585 .144 .674,000$ & 36 & $44.031 .796,490$ & & \\
\cline { 2 - 8 } & Total & $3.831 .429 .458,000$ & 39 & & & \\
\hline
\end{tabular}

Ket : a. Dependent Variable: Harga Saham

b. Predictors:(Constant), Ukuran perusahaan, Total Arus Kas, Laba bersih

Sumber: Hasil Output SPSS 24, 2018 (data diolah)

Berdasarkan hasil uji $\mathrm{F}$ diatas, nilai $\mathrm{F}_{\text {hitung }}$ 17,005 dan $\mathrm{F}$ tabel sebesar 2,858 yang artinya $F_{\text {hitung }} 17,005>F$ tabel 2,858 yang dengan tingkat signfikansi $0,000<0,05$. Hal ini berarti bahwa secara simultan variabel independen (laba bersih, total arus kas dan ukuran perusahaan) berpengaruh positif dan signifikan terhadap harga saham.

\section{Pengaruh Laba Bersih terhadap Harga Saham}

Hipotesis menyatakan bahwa laba bersih mempunyai pengaruh yang signifikan terhadap harga saham.Berdasarkan hasil uji secara parsial pada Tabel 4.9.Untuk variabel laba bersih diperoleh koefisien regresi dengan arah positif sebesar 0,186. Hal ini berarti bahwa pengaruh antara variabel laba bersih dengan harga saham adalah positif. Laba bersih memiliki nilai sig, sebesar 0 , dimana $0,000<0,05$ dan nilai $t_{\text {hitung }} 4,989>$ $\mathrm{t}_{\text {tabel }} 2,02819$, sehingga Ho ditolak dan Ha diterima. Dari penjelasan tersebut dapat disimpulkan bahwa variabel laba bersih berpengaruh positif dan signifikan terhadap harga saham sehingga hipotesisnya diterima.

Menurut Hery (2009:145) jika laba suatu perusahaan menunjukkan peningkatan dari waktu ke waktu, maka investor akan tertarik untuk menginvestasikan dananya pada perusahaan tersebut, dengan demikian harga saham yang dimiliki oleh perusahaan akan semakin meningkat, sehingga return saham akan meningkat pula. Hal ini terjadi karena laba perusahaan pada akhirnya akan meningkatkan nilai perusahaan dan meningkatkan kekayaan pemegang saham dalam bentuk naiknya harga saham. Laba bersih perusahaan salah satu faktor penting yang dilihat investor di pasar modal untuk menentukan pilihan dalam menanamkan investasinya. Salah satu investor dalam menanamkan dananya adalah dengan cara membeli saham. Perusahaan dengan laba yang tinggi mampu membayar dividen yang lebih tinggi sehingga dapat meningkatkan harga 
saham. Pada prinsipnya, membeli saham adalah untuk mendapatkan dividen serta menjual saham pada harga saham yang lebih tinggi. Laba bersih adalah kelebihan seluruh pendapatan atas seluruh biaya untuk suatu periode tertentu setelah dikurangi pajak penghasilan yang disajikan dalam laporan laba rugi. Sehingga hipotesis yang mengatakan bahwa terdapat pengaruh positif dan signifikan terhadap harga saham diterima.

\section{Pengaruh Total Arus Kas terhadap Harga Saham}

Hipotesis menyatakan bahwa total arus kas mempunyai pengaruh tidak signifikan terhadap harga saham. Berdasarkan hasil uji secara parsial pada Tabel 4.9, Untuk variabel total arus kas diperoleh koefisien regresi sebesar 0,134.Hal ini berarti bahwa pengaruh antara variabel total arus kas dengan harga saham adalah positif, total arus kas memiliki nilai sig, sebesar 0,062 dimana 0,062>0,05 dan nilai thitung 1,926 $<\mathrm{t}_{\text {tabel }} 2,02819$, sehingga Ho diterima dan Ha ditolak. Dari penjelasan tersebut dapat disimpulkan bahwa variabel total arus kas tidak berpengaruh dan tidak signifikan terhadap harga saham sehingga hipotesisnya ditolak.

Hery (2013:196) arus kas masuk dan arus kas keluar atau setara kas adalah investasi yang sifatnya likuid, berjangka pendek dan dapat dijadikan kas dalam jumlah tertentu tanpa menghadapi resiko perubahan nilai yang signifikan. Semakin besar arus kas yang dihasilkan perusahaan maka harga saham akan meningkat. Artinya perusahaan dapat mengahasilkan kas yang mampu melunasi pinjaman, memelihara kemampuan operasi perusahaan, membayar dividen, melakukan investasi baru tanpa mengandalkan pada sumber pendanaan dari luar, penerimaan dan pengeluaran kas sehubungan dengan sumber daya yang bertujuan untuk menghasilkan pendapatan arus kas masa depan. Total arus kas merupakan jumlah arus kas dari aktivitas operasi, inverstasi, pendanaan dan kas dan setara kas awal tahun.

Laporan arus kas melaporkan arus kas masuk maupun arus kas keluar perusahaan selama periode tertentu. Laporan arus kas ini akan memberikan informasi yang berguna mengenai kemampuan perusahaan dalam menghasilkan kas dari aktivitas operasi, melakukan investasi, melunasi kewajiban, dan membayar dividen. Laporan arus kas digunakan oleh kreditur dan investor dalam menilai tingkat likuiditas maupun kemampuan perusahaan dalam menghasilkan laba. Dalam penelitian ini arus kas tidak berpengaruh dan tidak signifikan terhadap harga saham hal ini disebabkan karena arus kas pada aktivitas pendanaan beberapa 
perusahaan sektor asuransi mengalami penurunan di tahun 2014. Hal ini menyebabkan investor tidak tertarik untuk menanamkan sahamnya pada perusahaan tersebut, karena perusahaan tersebut dinilai tidak mampu melunasi kewajibanya sehingga mengakibatkan penurunan harga saham pada perusahaan tersebut. Aktivitas pendanaan meliputi transaksi-transaksi yang dimana kas diperoleh atau dibayarkan kembali ke pemilik dana investor.

\section{Pengaruh Ukuran Perusahaan Terhadap Harga Saham}

Hipotesis menyatakan bahwa ukuran perusahaan mempunyai pengaruh yang signifikan terhadap harga saham. Berdasarkan hasil uji secara parsial pada Tabel 4.9, Untuk variabel laba bersih diperoleh koefisien regresi dengan arah negative sebesar -1.090,515. Hal ini berarti bahwa pengaruh antara variabel ukuran perusahaan dengan harga saham adalah negatif. Ukuran perusahaan memiliki nilai sig, sebesar 0,017, dimana $0,017<0,05$ dan nilai $t_{\text {hitung }}-2,490>t_{\text {tabel }} 2,0289$, sehingga Ho diterima dan Ha ditolak. Dari penjelasan tersebut dapat disimpulkan bahwa variabel ukuran perusahan berpengaruh negatif dan signifikan terhadap harga saham sehingga hipotesisnya ditolak.

Rima Fahmi Utami (2013:22) ukuran perusahaan merupakan nilai yang menunjukkan besar kecilnya perusahaan. Besar kecilnya perusahaan dilihat dari besar nilai equity, nilai penjualan atau nilai aktiva. Perusahaan dengan ukuran besar memiliki akses lebih besar dan luas untuk mendapat sumber pendanaan dari luar, sehingga untuk memperoleh pinjaman akan menjadi lebih mudah karena dikatakan bahwa perusahaan dengan ukuran besar memiliki kesempatan lebih besar untuk memenangkan persaingan atau bertahan dalam industri. Perusahaan besar memiliki total aset yang lebih besar pula sehingga dapat menarik investor untuk menanamkan modalnya pada perusahaan tersebut. Ukuran perusahaan adalah suatu skala dimana-mana dapat diklasifikasikan besar kecil perusahaan menurut berbagai cara, antara lain total aset, log size nilai pasar saham dan lain-lain. Berdasarkan total aset, ukuran perusahaan terbagi dalam tiga kategori yaitu perusahaan besar, perusahaan menengah dan perusahaan kecil. Perusahaan yang memiliki total aset besar menunjukkan bahwa perusahaan tersebut telah mencapai tahap kedewasaan. 


\section{KESIMPULAN DAN SARAN}

\section{Kesimpulan}

a. Laba bersih secara parsial berpengaruh positif dan signifikan terhadap harga saham.Maka peningkatan laba bersih akan diikuti peningkatan harga saham pada perusahaan Sektor Asuransi yang terdaftar di Bursa Efek Indonesia.

b. Total arus kas secara parsial tidak berpengaruh dan tidaksignifikan terhadap harga saham perusahaan sektor asuransi yang terdaftar di Bursa Efek Indonesia.

c. Ukuran perusahaan secara parsial berpengaruh negative dan signifikan terhadap harga saham, maka peningkatan ukuran perusahaan akan diikuti penurunan harga saham perusahaan Sektor Asuransi yang terdaftar di Bursa Efek Indonesia.

d. Variabel independen laba bersih, total arus kas dan ukuran perusahaansecara simultan berpengaruh positif dan signifikan terhadap harga saham perusahaan sektor asuransi yang terdaftar di Bursa Efek Indonesia.Semakin tinggi laba bersih maka akan semakin tinggi harga saham yang diperoleh perusahaan, semakin tinggi arus kas maka semakin tinggi harga saham yang diperoleh perusahaan dan begitu juga dengan ukuran perusahaan, semakin tinggi ukuran perusahaan maka harga saham juga semakin tinggi.

\section{Saran.}

Adapun saran-saran yang dapat diberikan penulis untuk penelitian selanjutnya adalah sebagai berikut:

a. Penelitian selanjutnya diharapkan dapat mempertimbangkan tanggal publikasi laporan keuangan, agar menggambarkan informasi yang sebenarnya. Benar informasi ketika laporan keuangan dirilis sehingga berpengaruh terhadap harga saham.

b. Penelitian selanjutnya diharapkan dapat memperluas penelitian dengan menambahkan jumlah variabel bebas, tahun periode dan jumlah sampel dalam penelitian. Tidak hanya berfokus pada perusahaan sektor asuransi saja, sehingga dapat diperoleh hasil penelitian dengan tingkat generalisasi yang lebih tinggi. 


\section{DAFTAR PUSTAKA}

Abdullah, Ibrahim (1993). "Kamus Manajemen Pemasaran dan Pemasaran Jasa" Cetakan Kedua. Penerbit Alfabeta. Bandung.

Bursa Efek indonesia. Laporan Tahunan Bursa Efek Indonesia.www.idx.co.id.

Brigham, Eguene F., dan Houston, Joel F. 2006. Dasar-Dasar Manajemen Keuangan.Edisi sepuluh. Alih Bahasa Ali Akbar Yulianto. Penerbit Salemba Empat. Jilid 1. Jakarta.

Brigham, Eugene dan Joel F. Houston, 2001.Manajemen Keuangan. Edisi Kedelapan, Buku Kedua, Terjemahan Dodo Suharto, Herman Wibiwo: Editor, Yanti Sumiharti, Wisnu Chandra Kridhaji. Erlagga, Jakarta.

Brigham, Eguene F., dan Houston, Joel F. 1998. Dasar-Dasar Manajemen Keuangan.Edisi sepuluh. Alih Bahasa Ali Akbar Yulianto. Penerbit Salemba Empat. Jakarta.

Fitri, Raisah. 2016. Pengaruh Laba Akuntansi dan Total Arus Kas Terhadap Harga Saham (Studi Pada Perusahaan Sub Sektor Property dan Real Estate yang Terdaftar di Bursa Efek Indonesia) .Jurnal.JIBEKA Volume 10, Nomor 1 Agustus 2016: 42-48.

Fitri, Raisah, dkk. 2013. Pengaruh Laba Akuntansi, Nilai Buku Ekuitas, dan Total Arus Kas Terhadap Harga Saham (Studi Pada Perusahaan Manufaktur yang Terdaftar di Bursa Efek Indonesia).Jurnal.Fakultas Ekonomi dan Bisnis Universitas Brawijaya Malang.

Fahmi, Irham. 2014. "Manajemen Keuangan Perusahaan dan Pasar Modal". Mitra Wacana Media. Jakarta.

Fahmi, Rima 2017.Pengaruh Ukuran Perusahaan, Leverage dan Profitabilitas Terhadap Harga Saham ( Study Pada Peursahaan Property dan Real Estate yang Terdaftar di Bursa Efek Indonesia 2014-2015) .Jurnal.Fakultas Ekonomi dan Bisnis Universitas Pasundan Bandung.

Hery.2013. Teori Akuntansi suatu pengantar. Jakarta: Lembaga Penerbit Fakultas Ekonomi Universitas Indonesia. 
Ikatan Akuntan Indonesia.2009, Pernyataan Standar Akuntansi Keuangan (PSAK) No.2, Penerbit Salemba Empat, Jakarta.

Jogiyanto. 2003. Analisis dan Desain Sistem Informasi : Pendekatan

Terstruktur Teori dan Praktek Aplikasi Bisnis (TH.2008). Yogyakarta:

Andi.

Kiesso, Donald E., Jerry J. Weygandt, dan Terry D. Warfield. 2005. Akuntansi Intermediate. Penerjemah Emil Salim. Edisi Keduabelas. Jilid Satu. Jakarta: Erlangga.

Pratama, Ariandi Yudi. 2015. Pengaruh Arus Kas Operasi dan Laba Bersih terhadap Harga Saham (Penelitian pada Perusahaan Sub SektorPerkebunan yang Terdaftar di Bursa Efek Indonesia Periode 2010 2014).Jurnal. Program Studi Akuntansi, Fakultas Ekonomi Universitas Komputer Indonesia.

Riduan, Akhmad. 2016. Pengaruh Profitabilitas, Leverage, Ukuran Perusahaan dan Kebijakan Dividen Pada Nilai Perusahaan. Surabaya: Sekolah Tinggi Ilmu Ekonomi Indonesia.

Silaen, Lia 2017. PengaruhLabaBersih, Total ArusKas, KebijakanDividendanPertumbuhanPenjualanTerhadapHargaSahamPada Perusahaan MakanandanMinuman yang Terdaftar di BEI Tahun 20122016. Medan.

Suyanti.2017.PengaruhPenjualan,

TotalArusKasdanLabaBersihTerhadapHargaSahamPada Perusahaan MakanandanMinuman yang Terdaftar di BEI Tahun 2012-2016. Medan.

Suwardjono. 2008. Teori Akuntansi Perekayasaan Pelaporan Keuangan. Yogyakarta: BPFE

Tamara Oca, Viandita, dkk.2013. Pengaruh Debt ratio,Price to Earning Ratio, Earning Per Share dan Ukuran Perusahaan terhadap Harga Saham(Studi Pada Perusahaan Manufaktur yang Terdaftar di Bursa Efek Indonesia) .Jurnal.Fakultas Ekonomi dan Bisnis Universitas Brawijaya Malang.

Tandelilin, E. 2001.Analisis Investasi dana Manajemen Portofolio. Yogyakarta: BPFE. 
Widodo, Wahyu. 2003. Pengaruh Informasi Arus Kas Terhadap Harga Saham Perusahaan LQ 45 di Bursa Efek Indonesia. Jakarta. Tesis. Semarang: Universitas Diponegoro.

www.yahoofinance.com 